\title{
Sus scrofa in the Czech Republic from the perspective of hunting statistics (Cetartiodactyla: Suidae)
}

\author{
Jan ANDRESKA \& Kateřina KRUPKOVÁ
}

Department of Biology and Environmental Studies, Faculty of Education, Charles University, M. D. Rettigové 4, CZ-116 39 Praha 1, Czech Republic;

jan.andreska@pedf.cuni.cz,krupkova95@seznam.cz

received on 18 November 2021

\begin{abstract}
The population of the wild boar (Sus scrofa) in the Czech Republic has been steadily increasing for the last 70 years. The only comparable tangible data are provided by the available harvest statistics. Disputes over the damage caused by wild boar are endless, and the dynamics of the species expansion have not yet been properly explained. The authors therefore present the harvest statistics as the only available data on which the wild boar population growth in the 20th century can be documented.
\end{abstract}

Key words. Wild boar, range species expansion, population development, hunting history.

\section{INTRODUCTION}

The wild boar (Sus scrofa Linnaeus, 1758) has become a successful returnee in the Czech wilderness, to the extent where it is questionable whether it actually is a success. The number of wild boars has been growing almost continuously since the end of the World War II, or more precisely from the moment of effect of the Act No. 225/1947 Coll. On hunting (AnONYMOUS 1947). The Act lifted the long-established ban on boar breeding in large-scale hunting grounds. The legal aspects of the legislator's intention are clear, it was unequivocally an attempt to combine, concise, and unify the old and hitherto valid legal norms for all parts of Czechoslovakia. The ban on free breeding did not apply to Slovakia, because the Hungarian Legal Article of 1883 did not implement such ban (ANONYMOUs 1886). This old legal norm was in effect in Slovakia until 31 December 1947, when it was repealed by the entry into force of the Act No. 225/1947.

In the past, the wild boar was completely exterminated from the Bohemian Lands, on the basis of imperial regulations from the second half of the 18th century. The issue was later addressed in detail by KOKEŠ (1987), who reliably refuted KOMÁREK's reasoning regarding the extinction of the wild boar as a result of epidemics (KoMÁREK 1955). ANDRESKA \& ANDRESKOví (1993) and ANDRESKA \& ANDRESKA (2016) also examined the issue of the wild boar extermination.

For long, there have been no centrally maintained statistics on the wild boar harvest. More complete data are provided by statistics, concentrated on the whole Austrian part of the Austrian-Hungarian monarchy in the period from 1874 to 1914 . At that time, the individual governorships, undoubtedly instructed by the Vienna Ministry of Agriculture, began to compile the data, which were subsequently published in the statistical yearbook of the Ministry (ANONYMOUS 
1875-1915). For the sake of clarity, we present and comment on the data obtained by excerpting via individual sections, with the proviso that they are, to our detriment, incomplete.

Only some estates kept their harvest statistics, with varying levels of preciseness. After the ban on the wild boar breeding in free hunting grounds, implemented in the Austrian part of the monarchy (1786), boars in the wild were completely exterminated in a relatively short time (SCHWENK 1985). As a result, with very rare exceptions, only harvests from game enclosures were reported. However, there were also proven exceptions. As an example, let us mention a group of wild boars that escaped from the Lány Game Enclosure (Central Bohemia) in 1904 and subsequently survived in the Křivoklát forests until 1928 (MAXERA 1935).

Additional statistics were kept by the authorities of Czechoslovakia starting from 1933, with specific results published with a considerable delay. The last published data are from 1937. Later data and data for the duration of the Protectorate of Bohemia and Moravia (1939-1945) are not available. Another line of the harvest data available starts in 1950 and ends with the year 2020 .

\section{RESULTS}

The data on the harvests of the wild boar in the Bohemian Lands (Bohemia, Moravia, Silesia) from the last period of remaining of Austria-Hungary (ANONYMOUs 1875-1915; Table 1) do not change significantly over a period of 41 years, with the only exception being 4,470 individuals reported to be harvested in Bohemia in 1879. Other great harvests are reported in 1898 and 1912. A precise explanation of the described anomalies is not provided. Zeros in terms of Silesia harvest do not necessarily mean there were no data recorded. There may have been zero harvest in the relevant years. Moreover, data from Silesia are repeatedly so low that their absence can be neglected, and the sum of the Bohemian and Moravian harvest can be considered a final figure.

The statistics for the particular provinces of Czechoslovakia in the 1930s (AnONYMOUs 1935-1939; Table 2) list harvests of the wild boar in game enclosures, while they list separately the harvest outside the game enclosures in large-scale hunting grounds and joint hunting grounds, which were leased hunting grounds. According to the Hunting Act in force in Bohemia, breeding of the wild boar outside the game enclosures was prohibited and, moreover, the game enclosure keeper was responsible for the damage caused by the game to any affected party. Therefore, boars in the wild (only escapers from game enclosures and migrants are to be considered) were intensively hunted and the creation of a breeding population in the wild was unthinkable.

A slightly different situation occurred in the Land of Moravia and Silesia (Table 2). There were fewer game reserve breeds than in Bohemia, and a logically higher possibility of penetration of individual animals migrating from Slovakia, where the law did not prohibit breeding in the wild. For comparison only, we present the situation in Slovakia in the same timeframe. A certain but still rather small part of the harvest number came from game enclosures, while the indisputably predominant number of boars was harvested in the wild. This reflects the local hunting legislation of the time. Please note that no game enclosures were established in the Land of Sub-Carpathian Ruthenia (currently the Trans-Carpathian Province of Ukraine), and boars were only hunted there in the wild, with the reported harvest being unexpectedly low.

The statistics kept for the whole Czechoslovakia in the period after 1950 are uninterrupted (Table 3), with the exception of the year 1959, which is not reported. The fact probably relates to the implemented administrative reform, when the borders of the regions were radically changed, which apparently caused confusion in the kept hunting statistics. To our detriment, 
Table 1. Harvest of the wild boar (Sus scrofa) in the Bohemian Lands between 1874 and 1914

\begin{tabular}{|c|c|c|c|c|}
\hline year $\backslash$ province & Bohemia & Moravia & (Austrian) Silesia & total \\
\hline 1874 & 499 & 179 & 36 & 714 \\
\hline 1875 & 730 & 156 & 24 & 910 \\
\hline 1876 & 701 & 159 & 51 & 911 \\
\hline 1877 & 586 & 131 & 16 & 733 \\
\hline 1878 & 560 & 282 & 22 & 864 \\
\hline 1879 & 4470 & 221 & 7 & 4698 \\
\hline 1880 & 788 & 343 & 3 & 1134 \\
\hline 1881 & 763 & 241 & 3 & 1007 \\
\hline 1882 & 746 & 231 & 6 & 983 \\
\hline 1883 & 802 & 265 & 0 & 1067 \\
\hline 1884 & 533 & 187 & 25 & 745 \\
\hline 1885 & 727 & 241 & 40 & 1008 \\
\hline 1886 & 565 & 199 & 35 & 799 \\
\hline 1887 & 749 & 187 & 0 & 936 \\
\hline 1888 & 508 & 216 & 3 & 727 \\
\hline 1889 & 939 & 278 & 3 & 1220 \\
\hline 1890 & 587 & 218 & 3 & 808 \\
\hline 1891 & 620 & 327 & 4 & 951 \\
\hline 1892 & 738 & 300 & 14 & 1052 \\
\hline 1893 & 915 & 219 & 0 & 1134 \\
\hline 1894 & 765 & 323 & 0 & 1088 \\
\hline 1895 & 843 & 234 & 0 & 1077 \\
\hline 1896 & 667 & 219 & 0 & 886 \\
\hline 1897 & 742 & 318 & 0 & 1060 \\
\hline 1898 & 1107 & 257 & 0 & 1364 \\
\hline 1899 & 748 & 421 & 0 & 1169 \\
\hline 1900 & 800 & 279 & 0 & 1079 \\
\hline 1901 & 875 & 381 & 3 & 1259 \\
\hline 1902 & 806 & 408 & 4 & 1218 \\
\hline 1903 & 763 & 270 & 7 & 1040 \\
\hline 1904 & 948 & 253 & 6 & 1207 \\
\hline 1905 & 726 & 173 & 3 & 902 \\
\hline 1906 & 744 & 264 & 0 & 1008 \\
\hline 1907 & 806 & 172 & 0 & 978 \\
\hline 1908 & 909 & 130 & 0 & 1039 \\
\hline 1909 & 786 & 108 & 0 & 894 \\
\hline 1910 & 882 & 136 & 4 & 1022 \\
\hline 1911 & 995 & 240 & 0 & 1235 \\
\hline 1912 & 1979 & 252 & 0 & 2231 \\
\hline 1913 & 845 & 208 & 23 & 1076 \\
\hline 1914 & 894 & 310 & 16 & 1220 \\
\hline
\end{tabular}

the game enclosure and wild breeds are not distinguished. Nevertheless, the statistics show the dynamics with which the harvest increased in Bohemia and Moravia over the reported period. After 177 years, effective 1 January 1948, the Hunting Act permitted the breeding of wild boar in the wild. Let us state here that the legislator significantly underestimated the wild boar ability 
Table 2. Harvest of the wild boar (Sus scrofa) in the particular provinces of Czechoslovakia between 1933 and 1937

\begin{tabular}{lccccrr}
\hline year $\backslash$ province & \multicolumn{2}{c}{ Bohemia } & \multicolumn{2}{c}{ Moravia and Silesia } & \multicolumn{2}{c}{ Slovakia } \\
& enclosures & total & enclosures & total & enclosures & total \\
\hline 1933 & 623 & 654 & 15 & 34 & 72 & 1815 \\
1934 & 271 & 272 & 6 & 11 & 62 & 1022 \\
1935 & 369 & 374 & 50 & 68 & 119 & 1246 \\
1936 & 128 & 199 & 1 & 5 & 97 & 1036 \\
1937 & 122 & 193 & 44 & 55 & 319 & 1739 \\
\hline
\end{tabular}

to migrate. There was a complete lack of experience with wild boar hunting at the time of their return to the wild. As a result, wild boars very quickly populated practically the entire territory of the Czech Republic. ANDRESKA \& ANDRESKoví (1993) described that as early as 1954, boars were present throughout Bohemia. In 1955, the reported harvest of the wild boar in the territory of the Czech Republic exceeded the numbers reported in Slovakia and continued to

Table 3. Harvest of the wild boar (Sus scrofa) in the Czech Republic and Slovakia between 1950 and 1975

\begin{tabular}{lccc}
\hline year & Czech Republic & Slovakia & total \\
\hline 1950 & 198 & 1107 & 1305 \\
1951 & 341 & 1324 & 1665 \\
1952 & 478 & 2378 & 2856 \\
1953 & 486 & 1922 & 2408 \\
1954 & 1205 & 1947 & 3152 \\
1955 & 1665 & 990 & 2155 \\
1956 & 1257 & 851 & 2108 \\
1957 & 1803 & 1176 & 2979 \\
1958 & 2086 & 1209 & 3295 \\
1960 & 3596 & 1790 & 5386 \\
1961 & 3941 & 2396 & 6337 \\
1962 & 4234 & 3041 & 7275 \\
1963 & 2781 & 2070 & 4851 \\
1964 & 2955 & 1673 & 4628 \\
1965 & 2837 & 2148 & 4985 \\
1966 & 2924 & 2321 & 5245 \\
1967 & 4153 & 3012 & 7165 \\
1968 & 3356 & 2172 & 5528 \\
1969 & 4971 & 2717 & 7688 \\
1970 & 4803 & 3548 & 8351 \\
1971 & 5120 & 3732 & 8852 \\
1972 & 6438 & 4069 & 10507 \\
1973 & 7566 & 4921 & 12487 \\
1974 & 9948 & 6075 & 16023 \\
1975 & 11763 & 6724 & 18847 \\
\hline
\end{tabular}


Table 4. Harvest of the wild boar (Sus scrofa) in the Czech Republic between 1976 and 2020

\begin{tabular}{|c|c|c|}
\hline year & total harvest & enclosures only \\
\hline 1976 & 13893 & - \\
\hline 1977 & 16104 & - \\
\hline 1978 & 14647 & - \\
\hline 1979 & 11103 & - \\
\hline 1980 & 11773 & - \\
\hline 1981 & 12341 & - \\
\hline 1982 & 10233 & - \\
\hline 1983 & 22790 & - \\
\hline 1984 & 23251 & - \\
\hline 1985 & 36048 & - \\
\hline 1986 & 31722 & - \\
\hline 1987 & 37563 & - \\
\hline 1988 & 47883 & - \\
\hline 1989 & 47817 & - \\
\hline 1990 & 55812 & - \\
\hline 1991 & 53010 & - \\
\hline 1992 & 39168 & - \\
\hline 1993 & 36565 & - \\
\hline 1994 & 37750 & - \\
\hline 1995 & 35312 & - \\
\hline 1996 & 41604 & - \\
\hline 1997 & 42585 & - \\
\hline 1998 & 60573 & - \\
\hline 1999 & 72929 & - \\
\hline 2000 & 67858 & - \\
\hline 2001 & 74196 & - \\
\hline 2002 & 81757 & - \\
\hline 2003 & 77269 & - \\
\hline 2004 & 121002 & - \\
\hline 2005 & 100030 & - \\
\hline 2006 & 59496 & - \\
\hline 2007 & 120329 & 2589 \\
\hline 2008 & 137898 & 3378 \\
\hline 2009 & 121185 & 2979 \\
\hline 2010 & 143378 & 3049 \\
\hline 2011 & 108789 & 2751 \\
\hline 2012 & 184144 & 3677 \\
\hline 2013 & 152250 & 3055 \\
\hline 2014 & 168974 & 3811 \\
\hline 2015 & 185496 & 3681 \\
\hline 2016 & 160139 & 3116 \\
\hline 2017 & 229182 & 3959 \\
\hline 2018 & 132369 & 2292 \\
\hline 2019 & 231014 & 3092 \\
\hline 2020 & 155561 & 2123 \\
\hline
\end{tabular}




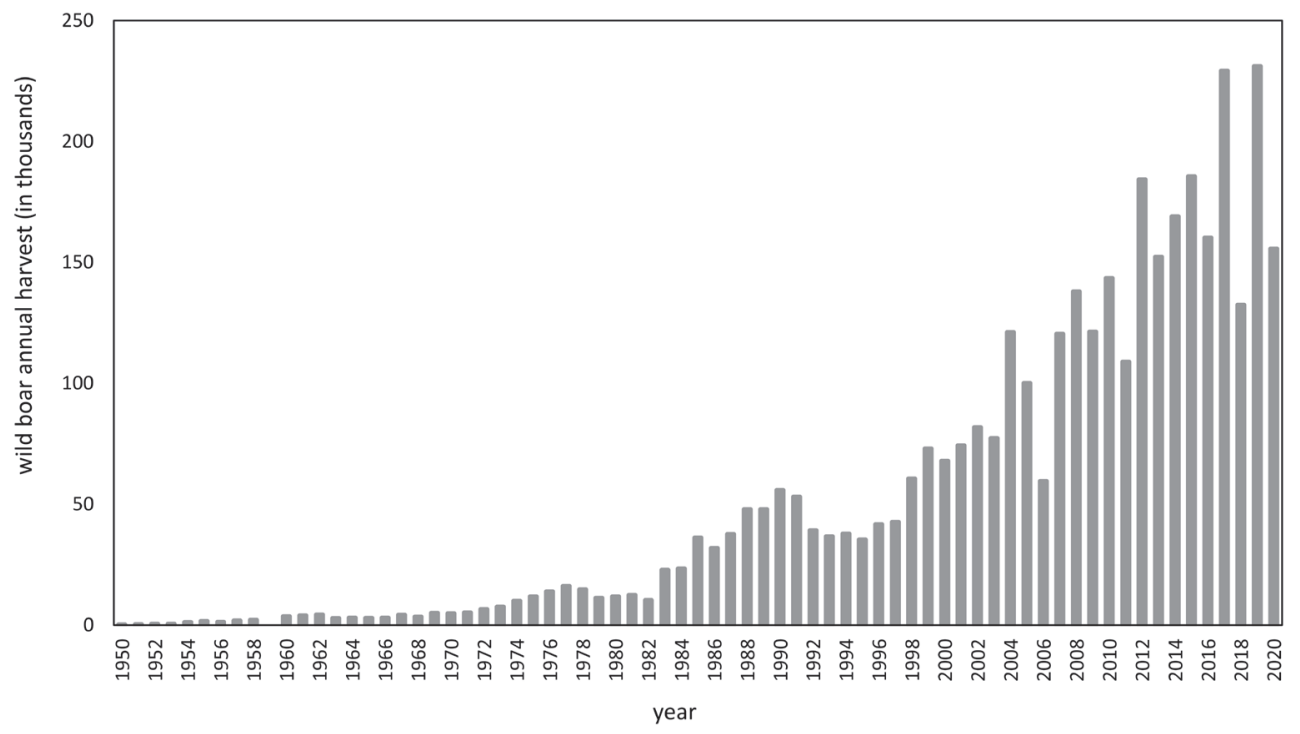

Fig. 1. Harvest of the wild boar (Sus scrofa) in the Czech Republic between 1950 and 2020.

grow. By 1958, they had grown ten times, by 1975 approximately 60 times. In Slovakia during the referenced period (1950-1975), the number grew only 6 times.

In the years 1976-2020, the reported harvests of wild boar in the Czech Republic continued to grow (Table 4). They did fluctuate and decrease at times, but the overall trend indicated an increase in harvested numbers and thus an increase in population of the species. In 2004, the reported harvest exceeded 100,000 individuals per year and in 2017 the figures grew well over 200,000 boars. The situation repeated in 2019. The increased harvest in 2017 was clearly a result of the implemented reward paid for each wild boar kill. This was the way the state administration logically responded to the occurrence of the African swine fever (ASF) in the Zlín Province (ANDRESKA \& ANDRESKA 2017). Concurrently, during the same year, a comprehensive monitoring of Aujeszky's disease was performed in the Czech Republic, also fuelled by the implemented reward payments. Since 2007, the harvest in game enclosures has also been reported, demonstrating an average annual catch of 3,110 individuals. However, the results do not differ much from the numbers reported some 150 years ago (1,133 individuals averaged over 41 years). Despite, there is a significant increase in the harvest of boars living in the wild. If we compare the years 1950 and 2019, the harvests in the Czech Republic increased 1,167 times (Fig. 1).

\section{DISCUSSION AND CONCLUSIONS}

Since there are no other hard data regarding the numbers of the wild boar (estimates of spring stocks are qualified, yet still estimates), the population size can be quantified only based on registered mortality, i.e., the number of reported killed individuals. The word reported is emphasised as, to ensure precision, the number would have to be supplemented with natural deaths, 
roadkills, and ultimately with unreported individuals. In 1980, by extrapolating the growth trend in the harvest, MotTL (1980) tried to estimate future harvest at 14,000 individuals, but this figure was exceeded for the first time in 1977. The predictions of the harvested numbers were therefore rather confusing.

Recently published studies suggesting that the current and growing numbers of the wild boar result from a shortage of hunters and their increasing age (e.g., KAMLER \& DRIMAJ 2021) do not explain the dynamic population growth between 1950 and 2020, i.e., during the time when the hunter population was rather large and expectedly in optimal condition. The less accepting attitude of today's society towards weapons and killing in general, which is mentioned by the same authors as a possible cause of the wild boar population growth, does occur, but still does not explain the above-referenced increases. A far simpler explanation lies in the legislative change that occurred in 1947, with effect from 1 January 1948. After the communist coup-d'état in 1948, there were fundamental changes in land ownership, which resulted in the occurrence of ample food opportunities. All the above combined has led to a sharp increase in the wild boar populations in the Czech Republic. Sufficient to surplus food, the absence of predators and the overall reluctance of the authorities responsible for supervising the state of the wild boar populations have fundamentally contributed to the subsequent development of the situation, the end result of which is the current state. The authors consider it indisputable that wild boars also behave as occasional carnivores and their massive presence in the landscape has had and continues to have an impact on the declining populations of small mammals and ground-nesting birds (KomáreK 1955, Melichar \& Vohralík 2019, VondrKa \& HrušKa 2021). However, this is not the subject of the present study.

The statistical summary indicates the development of harvest numbers of wild boar in the current territory of the Czech Republic since 1874. In the first interval (1874-1914), it is evident that the harvest of boars with regard to the legal standards prohibiting boar breeding in the wild did not increase in the long-term. A similar situation is evident from the incomplete data available from the period of the First Czechoslovak Republic (1933-1937).

The amendment of the law as of 1 January 1948, allowing breeding of the wild boar in the wild after approximately 170 years, and the immediately following changes in land ownership and management, caused a dynamic and long-term increase in the wild boar populations. The dynamics of the population growth were certainly influenced by the absence of predators, which are able to reduce especially the numbers of young individuals.

To our detriment, statistical data ceased to be collected in the period after the WWI outbreak. The resumption of the collection and publication of data related to hunting appeared long after the establishment of independent Czechoslovakia. The gap in the data spans 19 years. Similarly, the WWII caused another data gap, lasting 14 years. The Protectorate [of Bohemia and Moravia] Government Regulation from 31 March 1941 (ANONYMOus 1941) was the last legal norm that respected the ban on free breeding of the wild boar implemented by Joseph II in the 18th century. However, to our benefit, the collection of data published by the State Statistical Office since 1950 recorded the development of the harvest numbers of the wild boars that occurred after the entry into force of the Act No. 225/1947 Coll. (AnONYmous 1947). The population increase that occurred after the legalization of the wild breeding (1950-2020) is thus at least reliably documented. At the same time, it must be stated that the increase in numbers did not concern the game enclosures, where the old and new data do not differ fundamentally. The increase in harvested numbers relates solely to the part of the population that lives in the wild. The question remains what impact the measures against the spreading of the ASF will have on 
the wild boar populations, as the nearest outbreaks have been localised only tens of kilometres from the northern border of the Czech Republic, namely the Jizerské hory Mountains, at the time the article is drafted in the late 2021.

\section{SOUHRN}

Prase divoké (Sus scrofa) v České republice z perspektivy loveckých statistik (Cetartiodactyla: Suidae). Početnost populace prasete divokého (Sus scrofa) v př́rodě České republiky se již 70 let setrvale zvyšuje. Jediná porovnatelná konkrétní data poskytují dostupné statistiky úlovků (Fig. 1). Spory o škody působené divokými prasaty jsou nekončící a dynamika expanze druhu dosud není náležitě vysvětlena. Autoři proto předkládají dostupné statistiky úlovků jako jediná dostupná data, na kterých lze doložit zejména růst početnosti populace po roce $1950 \mathrm{v}$ důsledku změn právních norem upravujících pravidla chovu.

\section{REFERENCES}

ANDRESKa D. \& ANDRESKa J., 2016: Divoké prase na vzestupu [The Wild Boar on the Rise]. URL: https:// vesmir.cz/cz/on-line-clanky/2016/01/divoke-prase-vzestupu-vseho-moc-skodi.html.

ANDRESKa J. \& ANDreskoví E., 1993: Tisic let myslivosti [Thousand Years of the Game Management]. Tina, Vimperk, 442 pp (in Czech).

AnONymous, 1875-1915: Statistisches Jahrbuch des k. k. Ackerbau-Ministeriums. Forst- und Jagdstatistik. Verlag der k. k. Hof- und Staatsdruckerei, Wien.

AnONYmous, 1886: Magyar joganyagok 1883. évi XX. törvénycikk - a vadászatról [The Hungarian Legal Article XX. of 1883]. (in Hungarian).

Anonymous, 1935: Ulovená zvěř v r. 1933 [The game harvested in 1933]. Zprávy Státního Úřadu Statistického Republiky Československé, 16: 277-295 (in Czech).

ANONYmous, 1936: Ulovená zvěř v r. 1934 [The game harvested in 1934]. Zprávy Státního Úřadu Statistického Republiky Československé, 17: 1-8 (in Czech).

ANONYmous, 1937: Ulovená zvěř v r. 1935 [The game harvested in 1935]. Zprávy Státního Úřadu Statistického Republiky Československé, 18: 111-120 (in Czech).

Anonymous, 1938: Ulovená zvěř v r. 1936 [The game harvested in 1936]. Zprávy Státního Úřadu Statistického Republiky Československé, 19: 505-516 (in Czech).

Anonymous, 1939: Ulovená zvěř v r. 1937 [The game harvested in 1937]. Zprávy Státního Úřadu Statistického Republiky Česko-Slovenské, 20: 369-376 (in Czech).

ANONYMOus, 1941: 127/1941 Sb. Vládní nařízení ze dne 31. března 1941 o myslivosti [127/1941 of the Satute Book. The Game Management Government Decree from 31 March 1941]. Sbirka Zákonů a Nařizení Protektorátu Čechy a Morava, 1941: 445-483 (in Czech and German).

ANONYMous, 1947: 225. Zákon ze dne 18. prosince 1947 o myslivosti [225. The game management law from 18 December 1947]. Sbírka Zákonů a Nařizeni Republiky Československé, 1947(106): 1667-1686 (in Czech).

KOKEŠ O., 1987: Př́íčiny ústupu prasete divokého (Sus scrofa scrofa L., 1758) z českých zemí na přelomu 18. a 19. století. Lynx, n. s., 23: 119-125.

KomáreK J., 1955: Lovy v Karpatech [Huntings in the Carpathians]. Orbis, Praha, 312 pp (in Czech).

MaXera R., 1934: Myslivost'v hloubi lesư krivoklátských [The Game Management in the Deep of the Krivoklát Forests]. Unpubl. manuscript. Archive of the Hunting Museum Ohrada u Hluboké, 323 pp (in Czech).

Melichar V. \& Vohralík V., 2019: Předběžné výsledky mapování rozšíření křečka polního (Cricetus cricetus) v Čechách (Rodentia: Cricetidae) v letech 2012-2015 [Preliminary results of the survey of distribution of the common hamster (Cricetus cricetus) in Bohemia]. Príroda, 39: 113-122 (in Czech).

MotтL S., 1980: Koncepce rozvoje myslivosti a související problémy [The conceptions of development of the game management and related problems]. Pp.: 5-25. In: AnONYMous (ed.): Vývoj a perspektivy 
myslivosti [The Development and Perspecives of the Game Management]. Československá akademie zemědělská, Praha, 138 pp (in Czech).

Schwenk S., 1985: Österreichische Jagdstatistiken von 1850 bis 1936. Rudolf Habelt, Bonn, 203 pp.

VONDRKA A. \& HRUŠKA J., 2021: Jak se dař́ tetřevu hlušci na Šumavě? [How are wood grouse getting in the Šumava Mts.]. Živa, 69(6). 302-304 (in Czech).

Archive Records / Archivní prameny

Národní archiv České republiky [National Archives of the Czech Republic]. Fond: České místodržitelství. Sign. 12/183/2, 1884-1900, K 2514; Sign. 12/284/15, 1908-1910, K 6870; Sign. 12/310/41, 1872-1883, K 157, 158; Sign. 12/311/11, 1861-1867, K 160; Sign. 12/311/76, 1876, K 162.

Moravský zemský archiv v Brně [Moravian Provincial Archives in Brno]. Fond: B14 Moravské místodržitelství; K 2661; F 4614, 4664-4675

Zemský archiv v Opavě [Provincial Archives in Opava]. Fond: Zemská vláda slezská Opava, inv. č. 1144, Sign. 40/K-2, K 557, Výkazy odstřelené zvěře. konv.č. 8356/91; inv. č. 2122, Sign. VIII/74, K 4150, Honitba - pronájmy obecních honiteb, přestupky honebního zákona, doby hájení a odstřelu zvěre, hubení ondater; inv. č. 2122, Sign. VIII/74, K 4151, Honitba - pronájmy obecních honiteb, přestupky honebního zákona, doby hájení a odstřelu zvěře, hubení ondater. 